\title{
Increasing the uptake of Green Buildings-Insights from the Case study of an Apartment in Sri Lanka
}

\author{
Tanay Sinha \\ Overseas School of Colombo, Pannipitiya Road, Battaramulla, Colombo, Sri Lanka \\ DOI: 10.29322/IJSRP.10.11.2020.p10757 \\ http://dx.doi.org/10.29322/IJSRP.10.11.2020.p10757
}

\begin{abstract}
Sri Lanka has an immense potential for renewable energy given its location near to the equator. Colombo, and a large part of the Western Province, experiences 2620 hours of annual sunlight (approximately 7 hours every day). Furthermore, being a seaside island, it also experiences a fair amount of strong sea breeze on both the west and the east coast. Thus, Green buildings, leveraging renewable energies, have a huge prospect in Sri Lanka. In the long term, green buildings have a deep economic benefit, with lower energy footprint and hence low costs. Moreover, there is a positive environmental and social impact as well, with people becoming more aware of the advantages of being environment friendly. At the time of writing of this paper, Sri Lanka has 61 green buildings, out of which 30 are labelled (officially certified by the Sri Lankan Green Building Council). Despite these benefits, there seems to be a need to increase the uptake of green buildings in the country. The aim of this paper is to research and analyze the benefits and challenges in increasing the uptake of Green Buildings in Sri Lanka. This will be done by investigating the regulatory \& fiscal incentives, and economic and social benefits for/of the Green Building movement. The benefits and incentives will be compared with that of standard non green buildings. The paper will also analyze the challenges in terms of the capital requirements, cost of capital, capacity and the intent of the buyers/investors to pay for the premium required for green buildings. Apart from the analysis on Green buildings, the paper also analyzes the long-term energy roadmap of Sri Lanka and the role which renewable energy can play in securing Sri Lanka's energy security.
\end{abstract}

Index Terms- Green Buildings, Sustainability, Renewable energy, Energy Efficiency

\section{INTRODUCTION}

$\mathrm{T}$ he Green Building movement has the major potential to combat climate change by reducing $\mathrm{CO}_{2}$ emissions enabled by a more efficient use of energy ${ }^{1}$. The paper aims at presenting the tailwind factors of Energy Efficiency, Reduction in Water Usage, Improvement in Indoor Air Quality and Emotional Wellbeing \& the challenges related to the uptake of Green Building movement in Sri Lanka. The paper also analyzes the long-term energy roadmap of Sri Lanka and the role which renewable energy can play in securing Sri Lanka's energy security Sri Lanka is blessed with a moderate climate and medium population density. Traditionally Sri Lankans have always been living in harmony with nature and even today $\sim 81 \%$ of the population lives in villages - outside the municipal corporation/ body areas ${ }^{2}$. Majority of the households in the rural areas are low rise buildings with tiled roofs and large bay windows, which make them efficient in terms of energy management.

While some of the residential buildings have started to have sustainability features like Solar Roof, Water Recycling and harvesting, green spaces and green roof etc, very few buildings are certified Green Buildings. Waidyasekara and Sandamali (2012) state that there is very insignificant uptake of Green Building practices and there are many challenges to achieve the sustainability goal of Sri Lanka. ${ }^{3}$ There are only 61 certified buildings under GREENSL Rating (GBCSL, 2020).

Given this background the paper will be structured as follows - The first section will present the salient features of and the governance framework for Green Building (GB) \& Sustainable Energy (SE) and the current rating system for GB in Sri Lanka. This is followed by a case study of a residential apartment building that received a high GB \& SE rating. The case study involves analysis and presenting of the factors that helped the building get benefits and the GB rating. The paper concludes with recommendations for increasing the uptake of GB \& SE in Sri Lanka.

\section{Public Policy on Sustainable EnERgy AND GReEN BUILDINGS IN SRI LANKA}

Sri Lanka Sustainable Energy Authority is the governing body responsible for pioneering the sustainable energy revolution in Sri Lanka, aiming to facilitate the development of Sri Lanka's rich energy resources, including solar, wind, water and bioenergy. 4

As per the Sri Lanka Sustainable Energy Authority 4 "Sri Lanka is endowed with several types of renewable energy resources, including biomass, hydropower, solar and wind. Sri Lanka aspires to become a carbon neutral country by 2050 by making the most out of the energy available and developing cleaner energy resources according to the National Energy Policy and Strategies of Sri Lanka".

With such high aspirations on achieving carbon neutrality the Govt of Sri Lanka has drafted an "Energy Efficient Building Code $-2020 " 5$ and a Guideline for Sustainable Energy residences ${ }^{6}$ in Sri Lanka. The draft building code ${ }^{5}$ is aimed at "encouraging energy efficient design or retrofit of commercial buildings, industrial facilities excluding the process energy use and large scale housing developments, so that they may be designed, constructed, operated, and maintained in a manner that reduces the 
use of energy without constraining the building function, comfort, health, or productivity of the occupants and with appropriate regard for economic considerations".

The guideline for sustainable energy residences ${ }^{6}$ focusses on presenting a roadmap for sustainable housing elaborating on two aspects in the pursuit of comfortable housing in the Sri Lankan context: Energy Efficiency and Sustainability. The guideline discusses designing homes avoiding the climatic excess from the unique hot and wet climate of Sri Lanka yet leveraging the climate to improve energy efficiency.

Approximately $42 \% 7 \& 8$ of the power generated and consumed in Sri Lanka is dependent on liquid petroleum fuels. "As of 2017, Sri Lanka spent 29.5\% of its export earnings on fossil fuel imports. The country's financial resources therefore are heavily drained out of the country due to high import costs. Thus, veering away from imported energy resources and focusing more on renewable energy resources is deemed an urgent necessity" ${ }^{4}$.

Figure 1 ${ }^{7}$ : Represents Installed capacity in the current power system in Giga Watts and by technology type

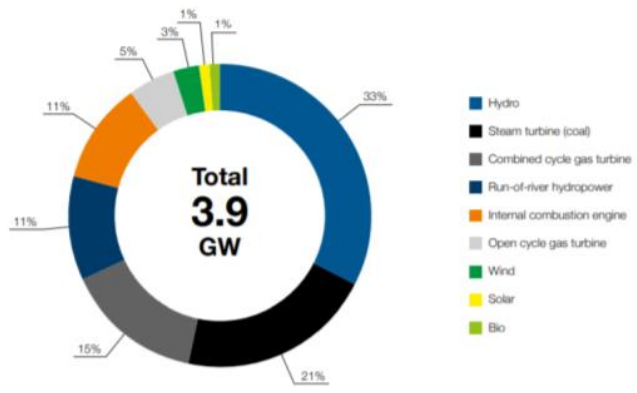

I. Salient Features of a Green Building

As per the US Energy Protection Website - "Green building is the practice of creating structures and using processes that are environmentally responsible and resource-efficient throughout a building's life cycle from siting to design, construction, operation, maintenance, renovation and deconstruction. This practice expands and complements the classical building design concerns of economy, utility, durability, and comfort. Green building is also known as a sustainable or high-performance building". ${ }^{9}$

\section{THE GOVERNANCE FRAMEWORK AROUND GREEN BUILDINGS IN SRI LANKA}

As of 2020, there are 61 Green Buildings and 30 of them are labelled/certified by GBCSL.

GBCSL is a consensus-based not for profit organization with diverse and integrated representation from all sectors of the property, industry and academia. GBCSL was established in 2009 with a joint effort by the professional institutions of architects, engineers, structural engineers, town planners, quantity surveyors, university academics, construction industry leaders, environmentalists and business leaders. ${ }^{10}$

\section{Rating System followed by GBCSL}

GBCSL has its own rating system GREENSL® Rating System, targeted at promoting high performance, healthy, durable and affordable environmentally sound practices in new and existing buildings. This rating system encourages builders and operators of such buildings to implement sustainable practices that reduce the negative environmental footprint of the buildings over their functional lifetime. The rating system considers the following eight metrics. ${ }^{10}$ 1) Management (MN) 2) Sustainable Sites (SS) 3) Energy and Atmosphere (EA) 4) Water Efficiency (WE) 5) Materials and Resources (MR) 6) Indoor Environmental Quality (EQ) 7) Innovation and Design Process (ID) 8) Social and Cultural Awareness (SC)

The salient features of the green building and availability of a supporting governance framework with a clear rating system in Sri Lanka there should have been a higher uptake of green buildings in the country. The Clearpoint Residences, a certified green building, in Colombo city is presented as a case study to illustrate the myriad of benefits of adopting such practices. The criteria of the GBCSL rating system provides a broad framework for the case study.

\section{ABOUt ClEARPOINT RESIDENCIES - SRI LANKA (REFERRED AS THE GREEN BUILDING IN THE SURVEY RESULTS) 11}

Clearpoint is the tallest residential vertical garden in the world, with planted terraces circling the entire structure and an inbuilt self-sustaining watering system. Guided by its cutting-edge yet holistic design approach, the building features several sustainability features that substantially reduce the energy and water consumption of its residents, whilst providing a level of comfort and luxury that is truly in harmony with nature. Some of the key and unique sustainability features of this GBCSL platinum rated Green building are as follows:

1. It has a large Solar Roof which powers the common areas and elevators and sells excess power to the grid.

2. Drip irrigated, planted terraces surrounding every apartment, which not only give a feeling of being connected with nature, but also improves air quality and reduces temperature. (Continued on Page 4)

3. Rainwater harvesting and Grey water recycling, using rainwater and recycled grey water to irrigate terraces and releasing surplus to the nearby water bodies sustaining a complete wet water ecosystem

4. Wedge design improving sunlight and cross ventilation in apartments thus reducing energy footprint

5. Electric charging points for hybrid vehicles

6. Centralized water heating system which is more energy efficient vs each apartment having a individual water heater

7. Solid waste segregation at source and upcycling through relevant agencies

8. Energy efficient elevators with port technology (grouping passengers for a cluster of floors) and regenerative drive technology which also saves energy.

9. Smart sensor-based lighting

\section{RESEARCH SPECIFIC TO THIS PAPER}

A web-based survey pointed towards people perceiving Green Buildings to be better/ more efficient on the following parameters. 
A. Energy Efficiency

B. Water Usage

C. Indoor Environment Quality

D. Emotional Wellbeing and outlook towards sustainability features

Using a web survey app, a questionnaire-based interview was conducted for around 100 residents of CPR and other buildings in Colombo. Experts were reached out in this area using telephonic interviews to understand their views on the subject.

\section{KEY FINDINGS}

There is a tangible benefit coming out of the sustainability features specially in the areas of energy on a per resident and per square foot basis. CPR being the only rated Green Building in this survey, had a significantly lower energy footprint (per resident and area) basis vs the other buildings surveyed.

\section{A. Energy Efficiency}

There is a very significant difference in the per capita electricity bills paid by the residents of Green Buildings with solar roofing. The average electricity bill per person for Green Buildings is $29 \%$ lower than that paid by others. If we look at the average electricity bill paid per square feet, the Green Buildings have a $55 \%$ lower outlay vs the others.

\section{B. Water Usage}

There is not a big difference in terms of per capita water bills paid by Green building residents vs the others. Green Building residents pay 3.8\% less than others. This is even though the Green Building has a water recycling system and the used water is cleaned and reused in toilet flushes. There is a scope to further clean the used water to water the green areas as well. That will require investment in advanced filtration systems, which don't work out economically as the cost of fresh water is very reasonable.

\section{Indoor Environment Quality}

The indoor environment quality in Green vs other buildings were also measured in terms of daylight efficiency, cross ventilation and impact of planted terraces on indoor temperatures. Using standard temperature gauges, it was found out that the Green Building Homes are cooler by 2- 4 degrees centigrade vs the others. This is because of the cross ventilation and the planted terraces in the Green Building acting as a buffer stopping the sunrays which would have otherwise warmed the homes.

The Green Building has one of the largest residential solar roofs in Sri Lanka; a feature which also keeps the Rooftop terrace cool and helps shading the swimming pool and hence saving on water evaporation.

The incidence of headaches, upper respiratory tract infections, eye irritation and fatigue, were also checked binarily with the respondents. These are typical indicators of poor Air Quality Index (AQI).

The Green Building residents have significantly lower levels of incidence of any of the above physical ramifications of poor AQI; Only $3 \%$ of the respondents in Green Building demonstrated these symptoms vs almost $9 \%$ in other buildings.

\section{Emotional Wellbeing \& outlook towards Sustainability features}

This publication is licensed under Creative Commons Attribution CC BY

http://dx.doi.org/10.29322/IJSRP.10.11.2020.p10757
The residents were also interviewed for understanding their wellness routines, rituals and optimism towards the future. Almost $86 \%$ of the Green Building Residents answered "Yes" to a question about the future being better than today; much higher than $57 \%$ who answered in affirmative for the same question in the Other Buildings. The timing of the survey with $\mathrm{C} 19$ pandemic raging across the world may have impacted the outcome of this question.

There was also a difference in the wellness and communal rituals of buildings with green communal spaces vs those without them. About $68 \%$ of Green Building residents confirmed the use of wellness facilities (Green area, Multipurpose Courts, Gym etc) vs $47 \%$ in other buildings which had these amenities.

$94 \%$ of the Green Building residents were aware of the Sustainability features of their building and its benefits; whereas this number was $80 \%$ in non-green ones. A staggering $93 \%$ of Green Building residents will be ready to pay a premium of average $15 \%$ for a Green Building vs a Non-Green one. This number drops to $51 \%$ in the non-green buildings.

\section{FISCAL AND REGULATORY INCENTIVES TO PROMOTE GREEN BUILDING AND RENEWABLE ENERGY}

Sri Lanka is blessed with abundant sunlight $(2620$ hours/year), high hydropower, wind energy and biomass potential and aspires to make its power sector carbon neutral by $2050^{8}$. The country has a very encouraging incentive offered to high end domestic consumers to avoid consumption in higher block tariffs in the domestic tariff system. ${ }^{12}$

Roof Top Solar power is being encouraged by the Government with high subsidies in terms of a buyback arrangement.

Solar service providers have implemented a system which exports the excess solar electricity generated from the domestic solar users to the national grid. In return, the Central Electricity Board (CEB) / Lanka Electricity Company Ltd (LECO)will pay the domestic user for the number of units contributed to the national grid by paying a sum of Rs. 22.00 per unit for the first seven years and Rs.15.50 for eight to twenty years. In other words, the consumer gets paid by the CEB / LECO when their solar system generates excess energy and shares the surplus units with the national grid. This payment arrangement is applied for 'Net Accounting' and 'Net Plus' solar scheme users.

Another incentive for the solar energy consumer is that they do not have to pay electricity bills unless their consumption is more than what is generated on their own roof top. This helps electricity consumers to reduce their bills up to zero and benefit with unlimited electricity usage ${ }^{13}$

\section{Challenges IN THE UPTAKE OF GREEN BuILDing MOVEMENT IN SRI LANKA.}

While there is a clear return of investment from Green Buildings, there are multiple challenges in terms of their scale up. The fact that very few residential buildings in Sri Lanka are Green rated speaks about the public awareness and demand for such a rating from prospective buyers. Green Buildings require very clearly laid out features and architectural designs, which many a 
time are overlooked by builders and buyers for higher Floor Area ratio (ratio between the total plot size and constructed space).

While the cost of Photo Voltaic cells is going down and there are substantial incentives ${ }^{14}$; the total installed capacity for roof top solar is $\sim 200 \mathrm{MW}$ and overall solar power contribution to the national power generation capacity is $\sim 5 \%$ only. ${ }^{12}$

While the CAPEX requirement for solar power has gone down, the cost for other sustainability and green features have remained stagnant along with real estate prices in Sri Lanka, thus making it increasingly difficult for builders to go for a Green rated residential or commercial building.

\section{CONCLUSION}

The aim of this paper was to present the tailwind factors of Energy Efficiency, Reduction in Water Usage, Improvement in Indoor Air Quality and Emotional Wellbeing \& the challenges related to the uptake of Green Building movement in Sri Lanka. The paper also analyzed the long-term energy roadmap of Sri Lanka and the role which renewable energy can play in securing Sri Lanka's energy security

From the research done, the following issues emerged:

A. Awareness: The concept of Green building and sustainability must be included in the school curriculum to build awareness about this important sustainability concept, in the next generation. Similarly, the public at large must be made aware of environmental, economic and social benefits of Green Buildings.

B. Encouraging Policy framework around Green Buildings and Sustainability: While there is a roadmap for Sustainable Finance published by the Central Bank of Sri Lanka $^{15}$, as of now there is no concessional cost of capital available for buyers and sellers of Green buildings. There is no tax incentive, other than the subsidy provided on roof top solar power to encourage Green buildings. There is a need for fiscal incentive-based policy-based encouragement for Green rated buildings including developing an accepted Green Building code and retrofitting non green buildings making them Green.

C. Alignment of stated objectives and long-term plans on Renewable energy: While the Government of Sri Lanka has announced a goal to reach $80 \%$ renewable energy by $2030^{7}$; currently there is an overdependence on Hydro power which has its own dynamicity because of seasonality of rains and climate change. The Ceylon Electricity Board has published a Long-Term Electricity Generation plan (LTGEP) in 2019. ${ }^{12}$ This plan outlines the roadmap towards energy security for Sri Lanka, in the next 20 years. The electricity demand in Sri Lanka is estimated to grow at $4.9 \%$ annually for next 20 years, somewhat in line with the GDP growth estimates. However, the LTGEP talks about a significant (55\%) share of renewables, majority of the capacity addition will be from Coal and other fossil fuels. There is very limited addition in Solar Power, despite the reduced CAPEX and cost of generation for Solar power. Sri Lanka has a potential to generate $7 \mathrm{GW}$ of Solar power and $4 \mathrm{GW}$ of wind power, catering to $40 \% \& 22 \%$ of the total projected power need of $17.6 \mathrm{GW}$ in $2037^{7}$. There is a need to align stated objectives with execution plans.

\section{ACKNOWLEDGEMENT}

I would like to acknowledge the support of Prof Mohan V Avvari, Associate Professor of Strategy and Innovation at Nottingham University Business School, Malaysia for guiding me in writing this paper.

\section{REFERENCES}

[1] https://sigearth.com/green-buildings-mitigate-climate-change/

[2] http://www.statistics.gov.lk/PopHouSat/CPH2011/Pages/Activities/Reports/ FinalReport/Population/Table\%20A1.pdf

[3] Waidyasekara, K.G.A.S. and Sandamali, R.L.N., 2012. Impact of Green Concept on Business Objectives of an Organization. In Proceedings of the World Construction Conference 2012 - Global Challenges in Construction Industry, Colombo 28-30 June 2012. Colombo: CIOB, 364-374.

[4] http://www.energy.gov.lk/en/renewable-energy/economic-benefits

[5] http://www.energy.gov.lk/images/resources/downloads/draft-eebc-2020.pdf

[6] http://www.energy.gov.lk/images/resources/downloads/ser-guideline-sep2020.pdf

[7] https://cdn.wartsila.com/docs/default-source/power-plantsdocuments/downloads/white-papers/the-optimal-path-for-greater-use-ofrenewable-energy-in-sri-lanka.pdf?sfvrsn=5e5ad444_2

[8] https://www.iea.org/countries/sri-lanka

[9] https://archive.epa.gov/greenbuilding/web/html/

[10] http://srilankagbc.org/

[11] https://www.maga.lk/clearpoint-residencies-becomes-the-highest-ratedgreen-building-in-sri-lanka/

[12] https://www.ceb.lk/front_img/img_reports/1591174971Revised_LTGEP_2 020-2039.pdf

[13] http://www.dailynews.lk/2018/01/31/features/141431/solar-powerelectricity-sri-lanka

[14] https://solarity.cz/blog/trends-for-pv-industry-in-2020/

[15] https://www.cbsl.gov.lk/sites/default/files/Sri\%20Lanka\%20Sustainable\%2 0Finance\%20Roadmap\%20FINAL\%2008.04.19.pdf

\section{AUTHORS}

First Author - Tanay Sinha, IBDP 2, Overseas School of Colombo, Pannipitiya Road, Battaramulla, Colombo, Sri Lanka. Email: tsinha21@osc.lk ; 21tsinha@gmail.com

Corresponding Author - Tanay Sinha, Overseas School of Colombo, Pannipitiya Road, Battaramulla, Colombo, Sri Lanka. Email: tsinha@21@osc.lk ; 21tsinha@gmail.com ; Contact Number: +94762767018 
